\title{
Effect of fertilization and microbiological bio-stimulators on healthiness and yield of organic potato
}

\author{
Wpływ nawożenia oraz biostymulatorów mikrobiologicznych \\ na zdrowotność i plonowanie ziemniaka w systemie ekologicznym
}

\author{
Jolanta Kowalska*
}

\begin{abstract}
Summary
The experiment on the assessment of the effects of the two microbial bio-stimulators (EM Farma Plus and UGmax) which were applied to soil, as foliar application or as combined were carried out on the field with organic cultivation of potato variety Ditta. Additional factor that is fertilization of the soil by application of fertilizer Bioilsa Fertil NC at $300 \mathrm{~kg} / \mathrm{ha}$ was included. The use of combined microbiological treatments (soil treatment before planting and 4 foliar applications during the growing season) significantly contributed to the increase in potato yields and participation in yield of trade tubers. Fertilization of potato plantation contributed to an increase by $19.5 \%$ in the yield of potato. Application of fertilization and microbiological treatments also increased the yield by 32.5\%. Microbiological treatments, regardless of the used product and the form of their application reduced the symptoms of late blight on no fertilized, average resistant variety. On the fertilized plants a reduction of late blight after treatments with EM Farma Plus was observed, regardless of the form of application compared to controls. The usefulness of both microbiological products in potato crop in both forms of application was confirmed.
\end{abstract}

Key words: fertilization; microbiological strengtheners; late blight; potato; yield

\section{Streszczenie}

Na plantacji ekologicznej z uprawą ziemniaka odmiany Ditta przeprowadzono doświadczenie dotyczące oceny wpływu stosowania dwóch biostymulatorów mikrobiologicznych (EM Farma Plus i UGmax) aplikowanych doglebowo, dolistnie lub w sposób łączony. Wprowadzono także dodatkowy czynnik badawczy - nawożenie poprzez doglebowe stosowanie nawozu Bioilsa Fertil NC w dawce $300 \mathrm{~kg} / \mathrm{ha}$. Stosowanie zabiegów mikrobiologicznych łączonych (doglebowo przed sadzeniem oraz 4-krotnie nalistnie w trakcie wegetacji) w sposób znaczący przyczyniło się do zwiększenia plonów ziemniaka i udziału w plonie plonu handlowego. Nawożenie plantacji ziemniaka zwiększyło plonowanie o 19,5\%, a stosowanie nawożenia i zabiegów mikrobiologicznych zwiększyło plon o 32,5\%. Zabiegi mikrobiologiczne, bez względu na stosowany produkt i formę jego aplikacji ograniczyły objawy zarazy ziemniaka na odmianie średnio odpornej nienawożonej. Na roślinach nawożonych obserwowano ograniczenie zarazy ziemniaka po zabiegach z biostymulatorem EM Farma Plus, bez względu na formę aplikacji w porównaniu do kontroli. Stwierdzono przydatność obu testowanych produktów mikrobiologicznych, stosowanych zarówno doglebowo, jak i dolistnie.

Słowa kluczowe: nawożenie; biostymulatory uprawy; zaraza ziemniaka; ziemniak; plon 


\section{Wstęp / Introduction}

Dodawanie preparatów mikrobiologicznych do gleby jest formą przyspieszenia procesu przywracania równowagi biologicznej i dobrostanu gleby. Stan ten jest jednym z wielu czynników odgrywających ważną rolę w zdrowotności upraw. Szczególnie istotny jest on w systemie rolnictwa ekologicznego, gdzie można go osiągnąć poprzez kilkuletnie stosowanie prawidłowych praktyk agrotechnicznych oraz przede wszystkim wieloletniego płodozmianu. Ochrona roślin w systemie ekologicznym nie jest rozpatrywana jako osobny etap w produkcji rolnej, ale jest to kompleks powiązanych ze sobą czynników, począwszy od prawidłowego przygotowania stanowiska, a kończąc na zabiegach ochronnych skierowanych przeciw konkretnym agrofagom występującym w nadmiernej liczebności. Jedną z praktyk rolniczych w zakresie ochrony roślin w systemie ekologicznym może być stosowanie mikroorganizmów pożytecznych.

Mikroorganizmy zawarte $\mathrm{w}$ preparatach znajdujących się na rynku, głównie w biostymulatorach rozwoju mogą konkurować o miejsce lub/i pokarm z patogenami. Stwarzają siedlisko sprzyjające rozwojowi roślin, biorą udział $\mathrm{w}$ procesach związanych $\mathrm{z}$ odżywaniem roślin poprzez przyspieszenie procesu rozkładu szczątków organicznych w glebie oraz zwiększanie dostępności mikro- i makroelementów dla roślin. Utrzymanie dobrostanu gleby jest kluczowym elementem sukcesu w produkcji ekologicznej, a stosowanie biologicznych środków produkcji może przyczynić się do produkcji żywności o wysokiej jakości w systemie przyjaznym dla agrofitocenozy.

Stosowanie preparatów mikrobiologicznych w produkcji roślinnej w Polsce budzi dużo kontrowersji. W literaturze znaleźć można doniesienia informujące o korzyściach ich stosowania (zwłaszcza z krajów tropikalnych) (Sangakkara i wsp. 2011) oraz o ich nieskuteczności (Martyniuk 2011; Martyniuk i Księżak 2011). Indywidualni producenci rolni wskazują jednak na pozytywny wpływ tych mikroorganizmów w uprawach, choć efekty ich stosowania nie są powtarzalne i pewne.

Niniejszy artykuł dotyczy oceny oddziaływania różnych preparatów mikrobiologicznych oraz sposobów ich stosowania na zdrowotność i plon ziemniaka uprawianego w systemie ekologicznym. Dodatkowo, z uwagi na to, że W systemie ekologicznym można stosować jedynie naturalne źródła azotu (nawozy organiczne, rośliny bobowate w płodozmianie), w badaniach uwzględniono czynnik nawożenia mający kluczową rolę w plonowaniu.

Celem badań była ocena przydatności dwóch mikrobiologicznych środków produkcji w ekologicznej uprawie wybranej odmiany ziemniaka w zależności od stosowanego nawożenia.

\section{Materiały i metody / Materials and methods}

Doświadczenie założono w Polowej Stacji Doświadczalnej w Winnej Górze metodą losowanych bloków w latach 2014-2015. Zastosowano nawóz zawierający azot organiczny, stopniowo uwalniający azot i dopuszczony do rolnictwa ekologicznego pod nazwą Bioilsa Fertil NC.
W badaniach czynnikiem I rzędu były stosowane biostymulatory mikrobiologiczne: EM Farma Plus lub UGmax, II rzędu - sposób stosowania tych produktów, a III rzędu nawożenie (stosowane lub jego brak). Wykorzystano odmianę Ditta - średnio wczesną o średniej odporności liści na zarazę ziemniaka. Dwa stymulatory wzrostu aplikowano w różnych formach (doglebowo, dolistnie i doglebowo-nalistnie). Przed sadzeniem bulw ziemniaka na wybranych poletkach zastosowano pierwszą aplikację z produktami EM Farma Plus i UGmax w dawce 40 i 1 1/ ha, odpowiednio. Ze względu na III czynnik doświadczenia nawożenie - powierzchnie doświadczalne zostały podzielone na dwie części: nawożoną wiosną nawozem Bioilsa Fertil NC w dawce $300 \mathrm{~kg} / \mathrm{ha}$ oraz nienawożoną. Dla każdego produktu mikrobiologicznego wykonano 4 zabiegi dolistne, osobno dla każdego produktu, pierwszy przed zwarciem rzędów, kolejny 10 dni po pierwszym zabiegu, w pełni kwitnienia i 10 dni po tym zabiegu. Zabieg przeciw stonce ziemniaczanej (Leptinotarsa decemlineata) wykonano w momencie pojawu pierwszych larw i był on oparty na środku SpinTor 240 SC, który aplikowany był w dawce $100 \mathrm{ml} / \mathrm{ha}$. Oceniano stopień porażenia roślin zarazą ziemniaka (sprawca Phytophthora infestans) zgodnie z wytycznymi EPPO (2008) na 20 losowo wybranych roślinach dla każdej kombinacji oddzielnie oraz zebrano plon ogólny, który został podzielony na frakcje. Wyniki badań opracowano statystycznie za pomocą analizy wariancji, a istotność różnic testowano testem Tukeya na poziomie istotności $\mathrm{p}=0,05$.

\section{Wyniki i dyskusja / Results and discussion}

Zastosowane $\mathrm{w}$ doświadczeniu nawożenie preparatem Bioilsa Fertil NC przyczyniło się do zwiększenia plonowania ziemniaka uprawianego $\mathrm{w}$ systemie ekologicznym. Najwyższe plony uzyskano $\mathrm{z}$ powierzchni, na której zastosowano nawóz Bioilsa Fertil NC oraz kombinację środka EM Farma Plus, aplikowanego doglebowo-dolistnie (średnio $15,1 \mathrm{t} / \mathrm{ha}$ ). Natomiast o około $20 \%$ niższy plon uzyskano $\mathrm{z}$ powierzchni, na której zastosowano nawóz Bioilsa Fertil NC, z równoczesnym stosowaniem doglebowo-dolistnym środka UGmax (średnio 12,5 t/ha). Wartości średnie zostały zaniżone $\mathrm{z}$ powodu niskich plonów uzyskanych w roku 2015 z uwagi na występującą suszę i wysokie temperatury powietrza. Połączenie zabiegów doglebowych $\mathrm{z}$ dolistnymi pozwoliło na uzyskanie wyższych plonów na powierzchni nawożonej, bez względu na zastosowany biostymulator. Najniższy plon zebrano z powierzchni nienawożonej (kontrolnej) (6,2 t/ha) (rys. 1).

Największy udział bulw handlowych (co najmniej $5,5 \mathrm{~cm}$ ) zarejestrowano na powierzchni nawożonej, gdzie stosowano EM Farma Plus doglebowo-dolistnie i UGmax doglebowo-dolistnie. Najniższy udział tych bulw stwierdzono na powierzchniach kontrolnych. Omawiana tendencja jest związana $\mathrm{z}$ plonem, co znalazło odzwierciedlenie w wysokości plonu. Zabiegi doglebowo-nalistne dla obu preparatów przyczyniły się do wzrostu udziału bulw jadalnych zarówno na powierzchni nawożonej, jak i nienawożonej. 


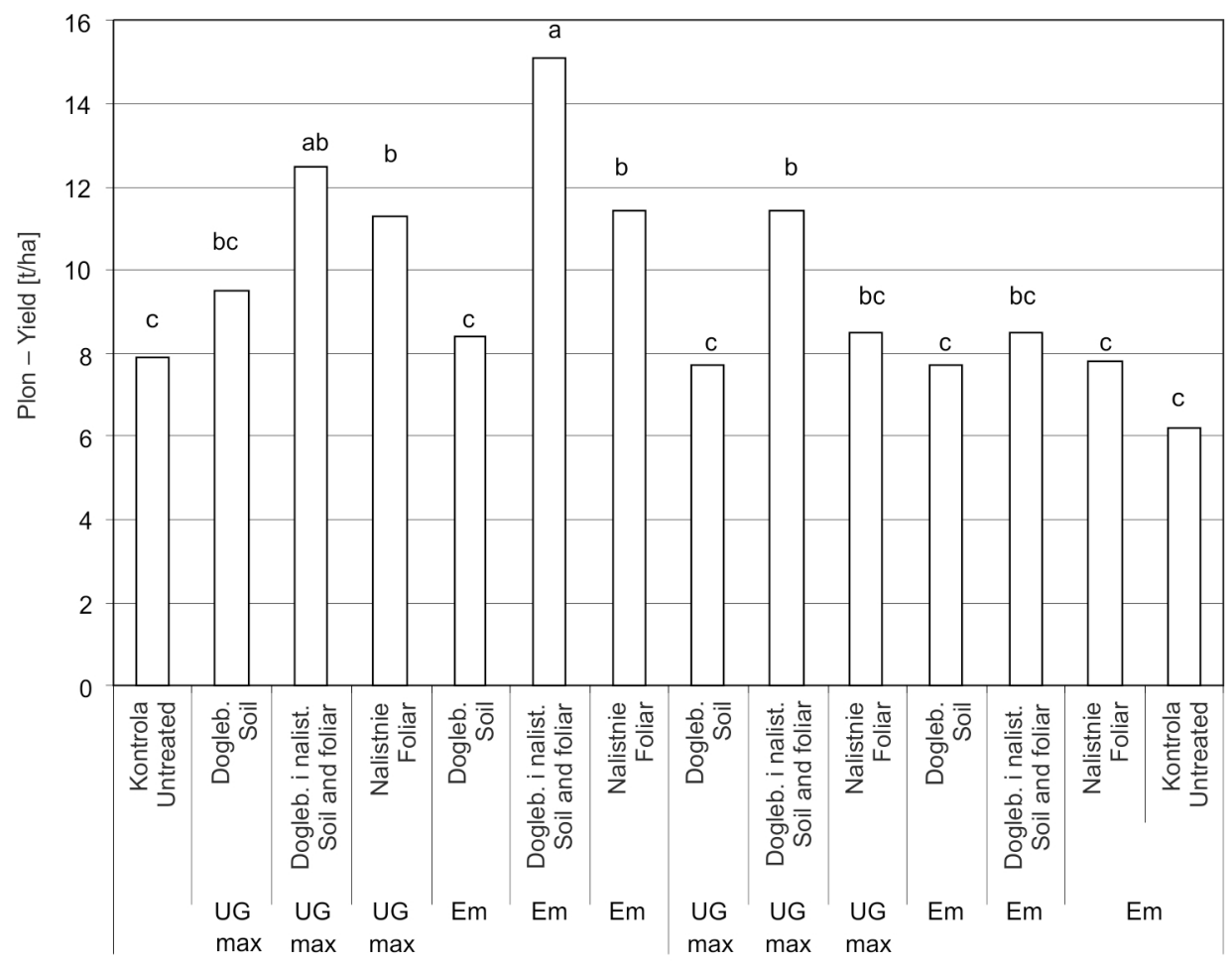

Bioilsa Fertil NC Bez Bioilsy - Non Bioilsa

Rys. 1. Plony ziemniaka (średnie z 2014-2015) w zależności od nawożenia i stosowanych preparatów biologicznych oraz form ich aplikacji

Fig. 1. Potato yields (mean from 2014-2015) in relation to application of fertilization and different forms of microbial treatments

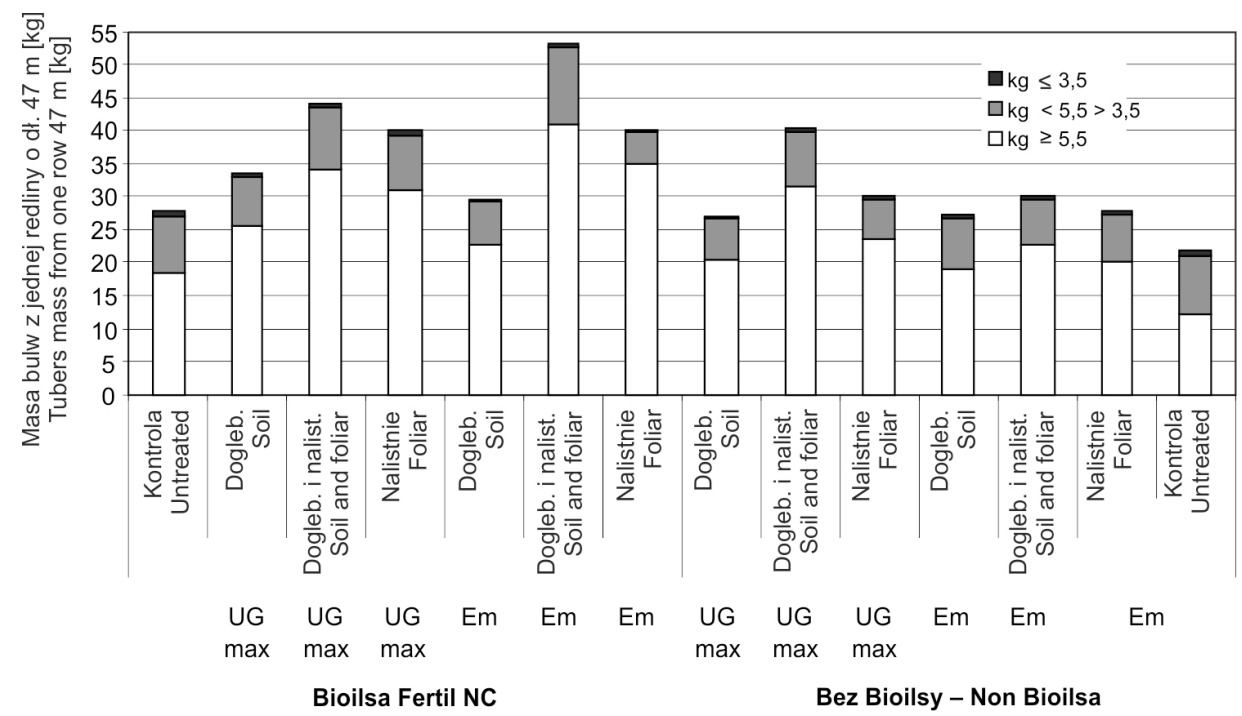

Rys. 2. Frakcje bulw ziemniaka z powierzchni traktowanej mikrobiologicznie w zależności od różnych form aplikacji i nawożenia Fig. 2. The fractions of potato tubers in relation to microbial treatments and application of fertilization

Nie stwierdzono wpływu testowanych czynników na zawartość skrobi w bulwach dla poszczególnych wariantów doświadczenia (rys. 3).

Zarówno EM Farma Plus, jak i UGmax były już testowane przez innych badaczy. Pietkiewicz i wsp. (2004) zaprawiali minibulwy ziemniaków przed sadzeniem w $1 \%$ roztworze Efektywnych Mikroorganizmów przez $30 \mathrm{mi}-$ nut. Nie stwierdzili wpływu zaprawiania na wschody, jedynie na fotosyntezę i stopień wykorzystania wody przez rośliny ziemniaka. Plon bulw otrzymanych $\mathrm{z}$ minibulw zaprawianych Efektywnymi Mikroorganizmami był podobny jak w kombinacji kontrolnej, ale niższy niż w kombinacji zaprawionej insektycydem (chemicznie zaprawą Prestige 290 FS). Zaprawianie insektycydem lub Efektywnymi Mikroorganizmami zmieniło udział w plonie bulw poszczególnych frakcji w porównaniu $\mathrm{z}$ kontrolą, przy czym w kombinacji z Efektywnymi Mikroorganizmami procentowy udział bulw w poszczególnych frakcjach był bardziej wyrównany. 


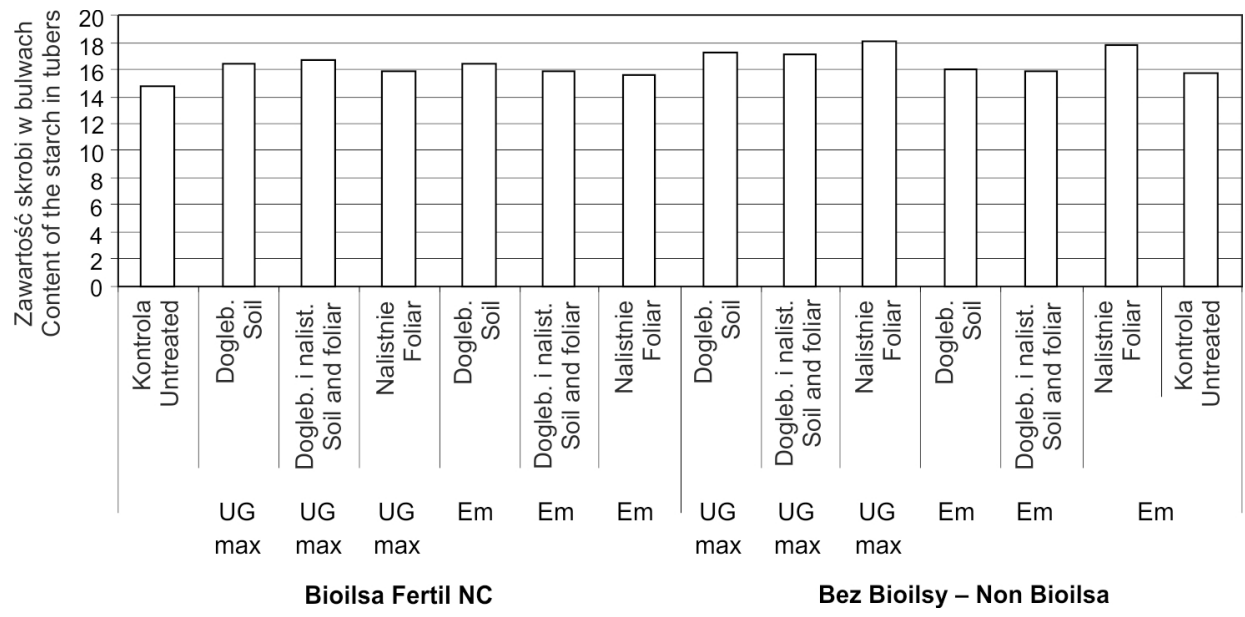

Rys. 3. Wpływ nawożenia i zabiegów mikrobiologicznych na zawartość skrobi w bulwach

Fig. 3. Effect of fertilization and microbial treatments on starch content in tubers

W badaniach własnych oceniano również zdrowotność roślin określając porażenie roślin ziemniaka przez zarazę. Wykonane zabiegi przyczyniły się do ograniczenia objawów Phytophthora infestans na roślinie (14,5-74\%) w porównaniu do powierzchni kontrolnej (77\% porażenia), szczególnie na powierzchniach nawożonych, gdzie obserwowano większe nasilenie choroby (tab. 1). Na powierzchniach nienawożonych ten efekt był mniej widoczny. Zabiegi z EM Farma Plus na roślinach nawożonych skuteczniej ograniczały nasilenie zarazy w porównaniu do zabiegów z UGmax. Na roślinach nienawożonych nie obserwowano różnic $\mathrm{w}$ nasileniu choroby w zależności od stosowanego produktu, formy jego aplikacji oraz w po- równaniu do kontroli. Zaobserwowano, że objawy choroby występowały w najmniejszym nasileniu na roślinach $\mathrm{z}$ poletek nienawożonych i traktowanych doglebowo EM Farma Plus (14,5\%). Należy jednak wspomnieć, że są to wartości średnie, silnie zaniżone przez bardzo niską presję choroby w roku 2015 z uwagi na suszę i wysokie temperatury.

Metody biologiczne w ochronie ziemniaka badali już inni autorzy, między innymi Cwalina-Ambroziak (2012), która oceniała skuteczność metod ochrony przed $P$. infestans i Alternaria spp. na odmianach wczesnych, tj. Asterix, Red Lady, Irga i Satina, stosując szczepionkę mikoryzową Glomus spp. (aplikowaną pod korzenie),

Tabela 1. Wpływ nawożenia i zabiegów mikrobiologicznych na występowanie objawów zarazy [\% powierzchni liści] na ziemniaku uprawianym w systemie ekologicznym (średnie z 2015)

Table 1. Effects of fertilization and microbial treatments on occurrence of late blight symptoms [\% of leaf area] on potato cultivated in organic system (mean from 2015)

\begin{tabular}{|c|c|c|c|c|c|c|c|c|c|c|c|c|c|c|}
\hline \multicolumn{15}{|c|}{ Zabiegi - Treatments } \\
\hline $\begin{array}{c}\text { Data } \\
\text { oceny } \\
\text { Date } \\
\text { of } \\
\text { assessment }\end{array}$ & 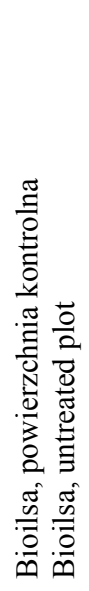 & 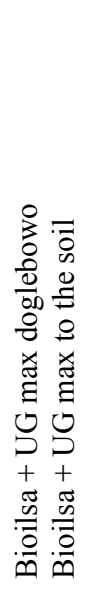 & 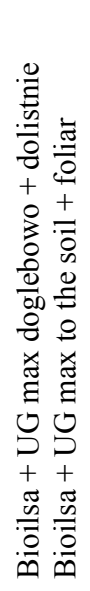 & 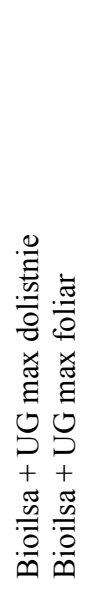 & 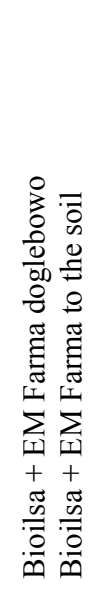 & 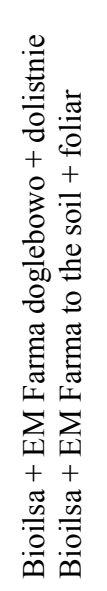 & 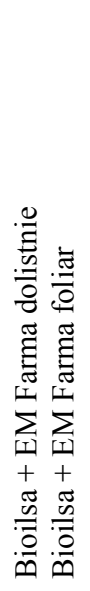 & 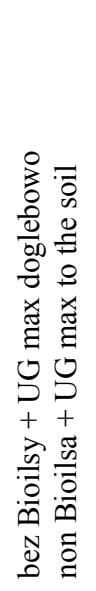 & 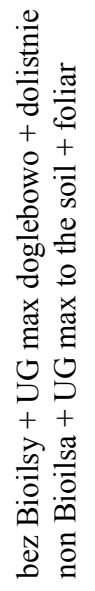 & 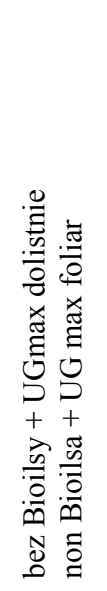 & 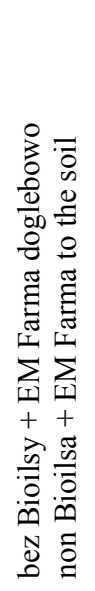 & 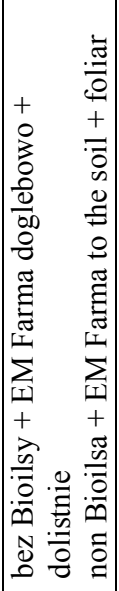 & 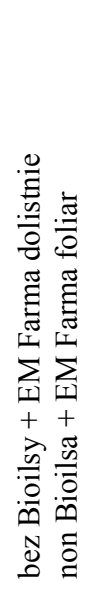 & 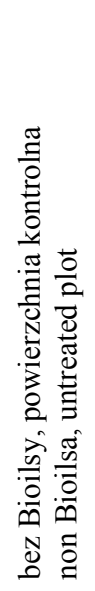 \\
\hline 13.07 .15 & 1,8 & 1,1 & 1,2 & 1,4 & 1,5 & 1,4 & 1,0 & 1,5 & 1,1 & 2,1 & 2,9 & 1,2 & 2,0 & 3,0 \\
\hline 20.07 .15 & 6,0 & 1,7 & 1,3 & 2,5 & 2,5 & 1,7 & 2,1 & 2,5 & 2,0 & 5,4 & 3,9 & 3,5 & 4,5 & 7,0 \\
\hline 03.08 .15 & $77,0 \mathrm{c}$ & $74,0 \mathrm{c}$ & $59,5 \mathrm{~b}$ & $66,5 \mathrm{c}$ & $31,0 \mathrm{ab}$ & $33,5 \mathrm{ab}$ & $215 \mathrm{a}$ & $19.0 \mathrm{a}$ & 18 & $34,0 \mathrm{ab}$ & $14,5 \mathrm{a}$ & $21,5 \mathrm{a}$ & $35,0 \mathrm{ab}$ & $20,5 \mathrm{a}$ \\
\hline
\end{tabular}

Analiza statystyczna dotyczy ostatniej daty obserwacji, wartości oznaczone różnymi literami w ramach wiersza oznaczają różnice istotne statystycznie Statistical analysis refers only to the last date of observation, values marked by different letters within the line indicate statistically significant differences 
Polyversum (zaprawianie bulw i 3-krotne opryskiwanie roślin w okresie wegetacji) i fungicydy (Infinito 687,5 SC + Tanos 50 WG, Valbon $72 \mathrm{WG}+$ Tanos $50 \mathrm{WG})$ w odstępach dwutygodniowych. Autorka ta stwierdziła ograniczenie występowania objawów $P$. infestans na ziemniaku na obiektach z ochroną biologiczną i chemiczną, najmniej porażona była odmiana Asterix. Alternarioza w słabszym nasileniu wystąpiła na roślinach opryskiwanych fungicydami, a biologiczne metody ochrony ziemniaka przed tą chorobą były nieskuteczne. Większą masę bulw uzyskano z roślin opryskiwanych fungicydem o działaniu systemicznym i wgłębnym - Infinito 687,5 SC oraz wgłębnym i kontaktowym - Tanos 50 WG niż dwoma fungicydami o działaniu wgłębnym i kontaktowym Valbon 72 WG i Tanos 50 WG. Odmiany nie różnicowały nasilenia choroby. Plon bulw w większym stopniu był uzależniony od warunków pogodowych i odmiany niż stosowanej ochrony.

Badania nad zastosowaniem mikrobiologicznych stymulatorów wzrostu zostały przeprowadzone na wielu różnych typach gleb i uprawach, w zróżnicowanych warunkach ekologiczno-rolniczych. Rezultaty niestety nie są powtarzalne, jednorodne $i$ trudno jest obecnie precyzyjnie ocenić ich skuteczność dla różnych upraw oraz na różnych typach gleb. Na glebach ciężkich zanotowano poprawienie parametrów gleby, produkt EM Farma Plus wyróżnił się też korzystnym oddziaływaniem na zwiększenie zawartości przyswajalnego fosforu, zasiedlenie gleby przez dżdżownice (najwyższa biomasa dżdżownic spośród innych stosowanych ulepszaczy) i plonowanie kukurydzy (Tyburski i Łachacz 2008). W pierwszym roku badań ci sami autorzy stwierdzili korzystny wpływ produktu Efektywnych Mikroorganizmów na własności fizyczne i strukturę gleby, ale zależności te nie potwierdziły się w drugim roku badań (Tyburski i Łachacz 2009). Dopełnieniem obrazu oddziaływania tych produktów jest ich wpływ na strukturę plonu. W wyniku zastosowania biopreparatu Efektywne Mikroorganizmy zarysowała się tendencja do zwiększenia obsady źdźbeł pszenicy jarej, której towarzyszyło nieznaczne zmniejszenie ich dorodności (Tyburski i Łachacz 2010). Natomiast z badań przeprowadzonych przez Trawczyńskiego i Bogdanowicza (2007) wynika, że zastosowany przez autorów w ziemniakach użyźniacz glebowy UGmax, spowodował istotny wzrost plonu ogólnego i plonu bulw dużych ziemniaka. Jabłoński (2009) po zastosowaniu UGmax w dawce 1,0 1/ha uzyskał zwiększenie plonu ogólnego o 12,2\%, a Frąckowiak-Pawlak (2011) na podstawie wyników z sześcioletnich badań odnotowała $30 \%$ przyrost plonu bulw ziemniaka jadalnego. Natomiast Maciejewski i Rębarz (2011) w jednorocznych badaniach stwierdzili, że zastosowanie UGmax nie miało wpływu na elementy plonotwórcze ziemniaka. Pod wpływem stosowania użyźniacza glebowego UGmax największy udział bulw badanych odmian o średnicy powyżej $60 \mathrm{~mm}$ i o średnicy od 35 do $60 \mathrm{~mm}$ stwierdzono po trzykrotnym stosowaniu UGmax, tj. przed sadzeniem, przy wysokości roślin ziemniaka 10-15 cm i w fazie pąków kwiatowych. Korzystny wpływ UGmax na wysokość plonu stwierdził także Bernat (2007). Ponadto Bernat (2007) oraz Zarzecka i wsp. (2011) odnotowali mniejszy udział bulw porażonych chorobami ziemniaka na obiektach, na których stosowano UGmax. Reasumując można stwierdzić, że wykorzystane stymulatory wzrostu mogą przyczynić się do zwiększenia plonu ogólnego i plonu bulw dużych (Zarzecka i Gugała 2012, 2013).

Formy stosowania środków wspomagających uprawę roślin są rozmaite, tak jak i uprawy, w których się je wykorzystuje. Z badań przeprowadzonych przez Zbroszczyk i Kordasa (2012) wynika, że autorzy ci nie stwierdzili istotnego wpływu zastosowanych mikroorganizmów na występowanie chorób podstawy źdźbła u pszenicy jarej. W literaturze można znaleźć prace wskazujące na pozytywny efekt ich zastosowania w uprawie chmielu (Solarska 2012), truskawki (Kowalska i Remlein-Starosta 2013) oraz w uprawie pszenicy i ziemniaków (Kuś 2013). Po jednorocznym zastosowaniu kompleksu probiotycznych mikroorganizmów pszenica jara reagowała istotnym wzrostem plonu. Stosowanie ich w ziemniakach zwiększyło nieznacznie plon odmian wczesnych, natomiast dla odmian późniejszych przyrost wynosił około 10\% (Kuś 2013).

Efekt plonotwórczy zastosowanych preparatów mikrobiologicznych można tłumaczyć pośrednio reakcją elicytacji (wzbudzenia) naturalnych sił obronnych roślin, poprzez zastosowanie pożytecznych organizmów (Walters i wsp. 2011; Kowalska i Remlein-Starosta 2012). Ponadto stwierdzono, że uzyskiwane plony nie są bezpośrednio skorelowane $\mathrm{z}$ nasileniem choroby. Efekt realnego spadku plonu występuje dopiero po przekroczeniu $60 \%$ porażenia roślin przez $P$. infestans i Alternaria spp. Zastosowanie testowanych preparatów opóźniło występowanie objawów choroby na roślinie, w konsekwencji wydłużyło wegetację (szczególnie przy niskiej presji choroby) i zabezpieczyło plon. Zabiegi mikrobiologiczne, bez względu na stosowany produkt, mogą więc przyczynić się do ograniczenia objawów $P$. infestans na odmianie średnio odpornej.

Dotychczas nie uzyskano powtarzalnych wyników zdecydowanie potwierdzających $100 \%$ przydatność stosowanych mikroorganizmów, bez ponoszenia zbędnych kosztów. Wytłumaczeniem tego faktu jest stwierdzenie, że są to organizmy żywe, które w różnych warunkach siedliskowych mogą reagować odmiennie, żywotność zawartych mikroorganizmów w produktach również podlega fluktuacji, ponadto każde stanowisko rolnicze wymaga podejścia indywidualnego uwzględniającego odpowiednią technologię stosowania tych produktów, aczkolwiek w przypadku upraw ziemniaka łączenie obu form aplikacji wydaje się być sposobem przynoszącym najkorzystniejsze efekty.

\section{Wnioski / Conclusions}

1. Stosowanie EM Farma Plus i UGmax w postaci zabiegów łączonych (doglebowo przed sadzeniem oraz 4-krotnie nalistnie w trakcie wegetacji) w sposób znaczący przyczyniło się do zwiększenia plonów ziemniaka i udziału w plonie bulw handlowych.

2. Przedsiewne nawożenie plantacji ziemniaka nawozem Bioilsa Fertil NC w dawce $300 \mathrm{~kg} /$ ha przyczyniło się do zwiększenia plonowania ziemniaka o $19,5 \%$, jednocześnie obserwowano nasilenie objawów $P$. infestans na roślinach nawożonych, co jednak przy niskiej presji 
choroby nie spowodowało istotnego spadku plonu. Ponadto włączenie mikrobiologicznych zabiegów dolistnych dodatkowo zwiększało plon o 32,5\%.

3. Nie stwierdzono istotnego wpływu badanych czynników na zawartość skrobi w bulwach dla poszczególnych wariantów doświadczenia.

4. Zabiegi mikrobiologiczne $\mathrm{z}$ biopreparatem EM Farma Plus, bez względu na formę ich aplikacji, przyczyniły się do ograniczenia objawów porażenia przez $P$. infestans na roślinach nawożonych w porównaniu do roślin ziemniaka z obiektu kontrolnego.
5. Forma aplikacji i rodzaj produktu nie miały wpływu na poziom infekcji przez $P$. infestans na roślinach nienawożonych.

\section{Podziękowanie / Acknowledgements}

Badania zostały sfinansowane przez Ministerstwo Rolnictwa i Rozwoju Wsi w ramach dotacji na rzecz badań dla rolnictwa ekologicznego, decyzja $\mathrm{z}$ dnia 15 października 2015 roku HORre-msz-780-15/15 (460).

\section{Literatura / References}

Bernat E. 2007. Wpływ stosowania Użyźniacza Glebowego na plonowanie i zdrowotność ziemniaków. Materiały Konferencji Naukowo-Szkoleniowa nt. Nasiennictwo i ochrona ziemniaka. Kołobrzeg, 19-20 kwietnia: 43-46.

Cwalina-Ambroziak B. 2012. Skuteczność biologicznej i chemicznej ochrony roślin ziemniaka przed zarazą (Phytophthora infestans /Mont./ de Bary) i alternariozą (Alternaria spp.). Polish Journal of Agronomy 11: 3-9.

EPPO 2008. Phytophthora infestans on potato. EPPO Bulletin 38 (3): 268-271.

Frąckowiak-Pawlak K. 2011. Wyniki wieloletnich doświadczeń z UGmax. Poradnik Gospodarski 2, s. 11.

Jabłoński K. 2009. Kierunki przewidywanych zmian w technologii produkcji ziemniaka do roku 2020. Studia i Raporty IUNG - PIB 17: $117-127$.

Kowalska J., Remlein-Starosta D. 2012. Wpływ częstotliwości i sposobu stosowania biopreparatu (Trichoderma asperellum) na ograniczenie występowania zarazy ziemniaka oraz na plon ziemniaków uprawianych systemem ekologicznym. [Influence of frequency and way of application of biopreparate (Trichoderma asperellum) on limitation of potato late blight and yield of organic potato]. Progress in Plant Protection/Postępy w Ochronie Roślin 52 (2): 347-350.

Kowalska J., Remlein-Starosta D. 2013. Zastosowanie Efektywnych Mikroorganizmów (EM) w ekologicznej uprawie truskawki. Zagadnienia Doradztwa Rolniczego 3: 46-55.

Kuś J. 2013. Wpływ preparatów biologicznych (ProBioEmów) na plonowanie pszenicy ozimej i jarej oraz ziemniaków w uprawie ekologicznej i konwencjonalnej. s. 275-286. W: Wyniki badań z zakresu rolnictwa ekologicznego realizowanych w 2012 roku. Warszawa-Falenty, Ministerstwo Rolnictwa i Rozwoju Wsi, 332 ss.

Maciejewski T., Rębarz K. 2011. Wpływ stosowania UGmax na rozwój i plonowanie ziemniaków i pszenicy ozimej. Doniesienie. Materiały Konferencji Naukowo-Szkoleniowej nt. Nasiennictwo i ochrona ziemniaka. Darłówko, 19-20 maja 2011, s. 35.

Martyniuk S. 2011. Skuteczne i nieskuteczne preparaty mikrobiologiczne stosowane w ochronie i uprawie roślin oraz rzetelne i nierzetelne metody ich oceny. Postępy Mikrobiologii 50 (4): 321-328.

Martyniuk S., Księżak J. 2011. Ocena pseudomikrobiologicznych biopreparatów stosowanych w uprawie roślin. Polish Journal of Agronomy 6: 27-33.

Pietkiewicz S., Kołpak R., Wiertrzyńska A., Łoboda T., Ostrowska D. 2004. Wpływ Efektywnych Mikroorganizmów na wzrost i plonowanie ziemniaków rozmnażanych z minibulw. Roczniki Gleboznawcze 1 (1): 285-290.

Sangakkara U.R., Wijesinghe D.B., Attana Yake K.B. 2011. Soil quality Phaseolus bean yields as affected by organic matter and EM in degraded tropical soil. p. 102-105. In: 16th IFOAM Organic World Congress. Italy, Modena. Organic Crop Protection, vo1. 1, $835 \mathrm{pp}$.

Solarska E. 2012. Dobre praktyki rolnicze w produkcji integrowanej z zastosowaniem pożytecznych mikroorganizmów w uprawie chmielu. Ministerstwo Rolnictwa i Rozwoju Wsi, Warszawa, 70 ss.

Trawczyński C., Bogdanowicz P. 2007. Wykorzystanie użyźniacza glebowego w aspekcie ekologicznej uprawy ziemniaka. Journal of Research and Applications in Agricultural Engineering 52 (4): 94-97.

Tyburski J., Łachacz A. 2008. Efektywność środków ulepszających gleby ciężkie w gospodarstwach ekologicznych. s. 87-98. W: Streszczenie wyników badań z zakresu rolnictwa ekologicznego realizowanych w 2007 roku. Ministerstwo Rolnictwa i Rozwoju Wsi, Warszawa, 209 ss.

Tyburski J., Łachacz A. 2009. Efektywność środków ulepszających gleby ciężkie w gospodarstwach ekologicznych. s. $221-227$. W: Streszczenie wyników badań z zakresu rolnictwa ekologicznego realizowanych w 2008 roku. Ministerstwo Rolnictwa i Rozwoju Wsi, Warszawa, 276 ss.

Tyburski J., Łachacz A. 2010. Efektywność środków ulepszających gleby ciężkie w gospodarstwach ekologicznych. s. $267-276$. W: Streszczenie wyników badań z zakresu rolnictwa ekologicznego realizowanych w 2009 roku. Ministerstwo Rolnictwa i Rozwoju Wsi, Warszawa, 318 ss.

Walters D., Havis N., Paterson L., Taylor J., Walsh D. 2011. Cultivar effects on the expression of induced resistance in spring barley. Plant Disease 5: 596-600.

Zarzecka K., Gugała M. 2012. Plonotwórcze działanie użyźniacza glebowego UGmax w uprawie ziemniaka. Inżynieria Ekologiczna 28: $144-148$.

Zarzecka K., Gugała M. 2013. Wpływ użyźniacza glebowego UGmax na plon ziemniaka i jego strukturę. Biuletyn Instytutu Hodowli i Aklimatyzacji Roślin 267: 107-112.

Zarzecka K., Gugała M., Milewska A. 2011. Oddziaływanie Użyźniacza Glebowego UGmax na plonowanie ziemniaka i zdrowotność roślin. [Effect of soil fertilizer UGmax on potato yielding and plant health]. Progress in Plant Protection/Postępy w Ochronie Roślin $51(1): 153-157$.

Zbroszczyk U., Kordas L. 2012. Wpływ stosowania Efektywnych Mikroorganizmów EM na zdrowotność pszenicy jarej uprawianej w krótkotrwałej monokulturze. [The influence of Effective Microorganisms EM ${ }^{\circledR}$ application on health status of spring wheat growing in short-term monoculture]. Progress in Plant Protection/Postępy w Ochronie Roślin 52 (3): 327-331. 